\title{
COMMENT
}

\section{INTERNATIONAL IEGAL EFFECTS OF DOLLAR DEPRECIATION}

ARThUR NUSSBatm*

W $\mathrm{WUL}$ primarily depreciation of national currency represents a grave change in economic relationships, at the same time it produces far-reaching repercussions within the field of law. This effect, painfully felt in other countries, has, up to the present, scarcely been noticed in the United States. Retail prices widely influencing the living standard are not yet fully adapted to the fall of the dollar, and insofar as prices have risen, public opinion attributes the increase to special and transient causes, such as the price fixing policy of the Code authorities, the recent drought, strikes and so on. Thus, some time may elapse before claims based essentially on the dollar depreciation (such as for allowance of higher maintenance) will be presented to American courts. Within the sphere of international relationships, however, legal consequences of the monetary measures taken by the United States have already appeared, and numerous others are to be expected. In this regard, controversies and decisions originating in the depreciation of the Pound Sterling, may be utilized to discern possible ways of future development.

The initial and dominant question is whether non-American courts will recognize the legal identity of the original and the devaluated dollar, i.e., whether they will decide according to the ruling: "dollar for dollar," thus applying the principle of "nominalism." Here, practically speaking, the case of an American dollar debtor sued before a non-American court demands particular consideration. Experience has shown that nearly all jurisdictions admit the principle of nominalism not only for their domestic, but also for foreign, currency. This is true particularly in English,

* Visiting Professor of Law, Columbia University; formerly Professor of Law, University of Berlin.

I Société des Hôtels v. Cumming, I26 L.T.R. ${ }_{513}$ (I92I) (concerning francs); Russian Commercial and Industrial Bank, [I921] 2 A.C. 438 (concerning roubles); in re Chesterman's Trust, $x_{3} \circ$ L.T.R. Iog (x923) (concerning marks); Anderson v. Equitable Assurance Co., I34 I.T.R. 357 (I926) (concerning marks); Perry v. Equitable Iife Insurance Co., 45 L.T.R. 468 (I929) (concerning roubles). 
French, ${ }^{2}$ Italian $^{3}$ and Dutch ${ }^{4}$ law. To this extent the American (and likewise the non-American) dollar debtors need not be afraid of being held liable, by foreign courts, beyond the contractual dollar amounts. The attitude of German courts, however, will probably be different. The Reichsgericht, supreme court of the Reich, in a judgment of June 2I, I933 granted compensation to a yarn trader who had suffered loss through monetary depreciation in the sale of merchandise against $£ .5$ The amount of the compensation was left to the discretion of the judge below who was directed to conform to equity in the widest sense of the word and to consider all the circumstances of the individual cases. It follows that the same position is likely to be held by German courts with regard to dollar contracts. German judgments are, under certain conditions, enforced in Danzig, in Austria and in Switzerland. Swiss courts themselves generally uphold nominalism. ${ }^{6}$ In cases of "Mark" debts, however, they showed a tendency toward "revaluation," but it is unlikely this will be extended to dollar debts. ${ }^{7}$

It would be incorrect to assume that there are not appreciable American dollar debts held abroad. Until r93 I and even later, the dollar has largely been considered to be a very stable monetary unit. Exporters from European and other countries, whose currencies were not held in such confidence, often preferred to have their contracts with American-and some times with non-American-importers phrased in dollars instead of their domestic currency. The same practice was followed sometimes in the leasing of quarters to Americans in Europe. In these and similar cases where American currency was contractually chosen on account of its believed stability, the question arises whether or not a tacit "gold clause" is contained in the contract, i.e. an implied obligation of the debtor to pay, in the contractual currency, the full equivalent, measured by gold, of the original debt. The problem has greatly been discussed in European jurisdictions with regard to contracts made in pounds, and despite contrary decisions arrived at by some courts of first resort, there has appeared

2 Judgments of the Cour de Cassation, dated April r2, I927; Journal du droit international (I928) $4 \mathrm{I} 4$ (concerning marks); ibid. (1929), I306 (concerning roubles).

3 Cf. Ascarelli, Rivista del diritto commerciale (1932), 60r, and note.

4 Judgment of the Haage Raad, dated January 2, r93r; Nederlandsche Jurisprudentie (I93I), 274 (concerning marks).

${ }^{14}$ I Entscheidungen des Reichsgerichts in Zivilsachen, 212.

${ }^{6}$ See Nussbaum, Deutsches Internationales Privatrecht (1932), 445 et seq.

7 Judgments of the Swiss Federal Tribunal dated June 3, 1925, and February I7, I927; 5 I Amtliche Sammlung der Entscheidungen des Schweizerischen Bundesgerichts, II, 303; and 53 ibid., II, 276. 
a remarkable conformity among Austrian, ${ }^{8}$ Belgian, ${ }^{9}$ Dutch, ${ }^{10}$ French, ${ }^{\text {Ir }}$ German, ${ }^{12}$ and Swiss ${ }^{13}$ higher courts to deny the existence of a tacit gold clause. The same attitude has been taken by a Canadian Court ${ }^{x_{4}}$ and by a number of prominent arbitrators and Arbitration Courts. Particularly was this true in the case of several awards emanating from different arbitrators of the International Chamber of Commerce in Paris. ${ }^{x 5}$ Not that the possibility of a tacit gold clause was denied, on the contrary it was universally admitted that the gold clause does not need express wording, but the general attitude of courts and arbitrators on this score turned out clearly unfavorable towards the creditors' claims. Only if substantial evidence could be taken from the provisions of the contract to the effect that an obligation for the actual gold value was intended by the parties, would such an obligation, although not expressly incorporated in the contract, be judicially recognized. Thus the Supreme Court of the United States, in the famous case Trebilcock v. Wilson construed an agreement to pay a dollar "in specie" to be a gold clause. ${ }^{16}$ But the German Appellate Court of Cologne, in a recent decision, denied the assumption of a gold claim even in a case where a Swiss life insurance company had in I927 obligated itself to pay " 50,000 goldmarks" under the provision that the goldmark should be $\frac{10}{4} \frac{0}{2}$ of the U.S.A. dollar. The fact that this fraction represents the original parity between dollar and mark and the express reference made by the use of the word goldmark to gold were considered immaterial by the court. ${ }^{17}$

${ }^{8}$ Judgment of the Supreme Court of Austria dated May 5, I932 in Die Rechtsprechung (Vienna, I933), Iog.

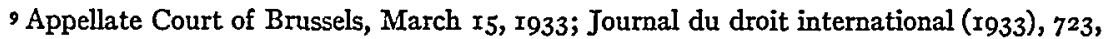
724; Tribunal civil of Antwerp (March 15, 1933), 722, 725; contra: Tribunal civil of Brussels (December 15, 1932; eod. r933), 723.

10 Cf. Judgment of the Haage Raad (January 2, I93I); Nederlandsche Jurisprudentie (193r), 274 .

II Several decisions to this effect have been published in the Gazette du Palais (I933), II, 27, et. seq.

${ }^{12}$ Appellate Court of Hamburg, June I4, 1932, in Hanseatische Rechts- und Gerichtszeitschrift (r932), B, 593 .

${ }^{23}$ Federal Tribunal, May 23, I928; Journal du droit international (1929), 497.

14 In Brown v. Alberta and Great Waterways Railway, 59 D.L.R. 520 (I92I), see infra, n. 17.

${ }^{45}$ World Trade, Journal of the International Chamber of Commerce (Paris, I932), no. 9, p. Io; no. II, p. II; (I933), no. 2, p. 10; no. 5, p. II.

${ }^{26} 79$ U.S. 687 (187r).

17 Judgment of Sept. 28, I934; 34 Bankarchiv 63. Although the case is on the border line I think the court is right. There could be no doubt as to the correctness of the decision, were 
The general rule "dollar for dollar" does not, possibly, apply as far as a breach of contract is concerned. If the dollar debtor defaults in payment and the dollar subsequently declines in terms of gold, foreign courts will, as a rule, hold the debtor liable for recovery of the loss in value. It is true that most foreign laws, particularly English ${ }^{18}$ French $^{\mathrm{x} 9}$ and Italian, ${ }^{20}$ limit recovery of damages to legal interest regardless of any monetary depreciation, if the effects of non-payment are in question. But this rule, prevailing also in the United States, ${ }^{2 x}$ is mostly confined to payments owed in domestic currency, for instance in francs under the French legal system. ${ }^{22}$ English courts convert money due in any non-English currency, irrespective of the legal system involved, into English currency at the rate of exchange existing at the time of default. ${ }^{23}$ This rule denies the dollar creditor protection against the loss in case the pound, within the period concerned, goes down in terms of gold more or just as much as the dollar. American

it not for the use of the "goldmark" phrase. See Brown v. Alberta and Great Waterways R. 59 D.L.R. 520 ( $x_{921}$ ). There was laid before the Alberta Supreme Court, Appellate Division, an interest coupon phrased in these terms: "The company will pay to bearer . . . of lawful money of Canada at the fixed rate of exchange of $\$ 4.862 / 3$ for the pound sterling .... in Iondon, England, being half yearly interest at the rate of $5 \%$ per annum on the above debenture bond." The bond ran on rooo (Canadian) dollars, which were at the time of the judgment at a considerable premium over sterling. The plaintiff claimed twenty-five Canadian dollars, but the Court held that only pounds sterling at the rate mentioned above, amounting to $£_{5.2 .9}$, were owed. On the other hand sometimes perfectly clear gold clauses sometimes have been disregarded by courts. Thus in Derwa v. Rio de Janeiro Tramway, Light and Power Co. ${ }_{4}$ D.L.R. 542 (1928), a bond headed and indorsed as "Obligation de cinq cents francs $5 \%$ or" ( 5 per cent gold bond), payable in Paris, Brussels or Toronto, was to be construed by the Ontario Supreme Court. The court, by a very daring construction of the bond, reached the surprising conclusion that the debtor was obligated only for the face amount of depreciated francs. Several other decisions of a similar kind are reported in Nussbaum, La clause- or dans les contrats internationaux, 43 Recueil des cours professés à l'Académie de droit international de la Haye, $5^{8} 5$ et seq.

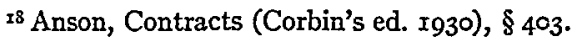

19 Code Civil, art. Ir53.

${ }^{20}$ Codice Civile, art. ז23x. See n. 22.

${ }^{2 x}$ Cf. 2 Williston, Contracts (I929), I4IO.

${ }^{22}$ Cf. for French law, Court of Cassation (February 25, I929), affirming Appellate Court of Paris (February r8, I927), Journal Droit International (r929), I306; Trib. Civ. de la Seine (February 23, I927; eod. 1927), ro6o. In Italy the attitude of the courts is extremely inconsistent. For a collection and criticism of Italian cases see Montel, in VI Annuario di Diritto Comparato, I (I93r), 567. Recently, the Realm's Court of Cassation has advanced the surprising solution that the debtor of foreign money is given the benefit of Codice civile, art. I23I, in case he pays contractual currency, whereas he is liable to indemnify the creditor for depreciation in case he pays in Italian currency which is, as a rule, in his choice under Italian law. Judgment of January I5, I934, I Foro Italiano (1934), 39I.

${ }_{23}$ Di Fernando v. Simons, Smith \& Co., [I920] 3 K.B. 409, Ullendahl v. Pankhurst, Wright \& Co., 39 T.I.R. 628 (I923). 
courts follow the same rule with regard to foreign currency. ${ }^{24}$ Debts in the currency of a "gold block" country would be particularly affected. Suppose a franc debt fell due in February, I933, and judgment is given now, then conversion, by the court, of francs into dollars must be made at the former gold parity. Under the rule mentioned the creditor would have to suffer a loss of more than forty per cent, although the debtor broke the contract. There is, however, this peculiar difference under American law: if the debt, contracted in foreign currency, has to be paid outside the United States, the exchange rate existing at the entering of the judgment is considered to be decisive. Moreover, the question as to whether the creditor, in the first case, is entitled to compensation if the dollar, subsequently to the breach of the contract, has declined in value, seems not yet to be settled. It may be mentioned in passing that the English American method of requiring the conversion of foreign currency debts into domestic currency debts, by judgment, is not self evident at all. It alters the terms of the contract and defeats the common intent of the parties in making it. Hence, problems are bound to arise unknown to other legal systems and impossible of a really satisfactory solution.

Hitherto we have contemplated the effect of depreciation upon debts. Depreciation, however, may interfere also with pending contracts. Suppose a French or German manufacturer, before the abrogation of the gold standard, sold merchandise to an American department store, to be delivered in instalments within a two-year period, for a fixed payment in dollars. May not the foreign manufacturer refuse further deliveries in the face of depreciation if he is not offered an equitable increase in the original price? In leading continental systems a definite ruling has not yet been established, but a distinct trend of opinion is in favor of the obligor. The old medieval doctrine that the parties' rights to performance are, to a certain extent, conditioned on the continuation of the status quo (that a tacit clausula rebus sic stantibus is inherent to the contract), after being forgotten in the happy Igth century, has been resurrected in various doctrinal forms since the war. ${ }^{25}$ It offers the proper argument for dealing with situations such as are brought about by a subsequent depreciation of the contractual currency. The attitude of Anglo-American law is much stricter; it gives the obligor no relief if performance becomes, by an alteration of general conditions, economically oppressive and even ruinous.

24 Hicks v. Guinness, 269 U.S. 7I, 80 (I925), Deutsche Bank v. Humphrey, 272 U.S. 5 I7 (1926); see also The Integritas, 3 F. Supp. 89I (I933).

${ }^{25}$ Dawson, Effects on Inflation, etc., 33 Mich. L. Rev. I7r, I75 (I934); 2 Rechtsvergleichendes Handwörterbuch 634; Planiol v. Ripert, VI Traité pratique de droit civil (1930), no. 39 I et seq. 
Therefore, as regards dollar depreciation, the legal situation of an American exporter bound to future deliveries will, in general, be worse than that of a foreign exporter who has sold against dollars, for in the first case under International Private Law, American rules will probably apply. The uncertainty and inconsistency as well as the serious consequences of the rule in question appear a remarkable contribution to the hardship which is inflicted on foreign trade by monetary depreciation, and impairs even existent legal relationships.

It is, however, the American "Joint Resolution" of June 5, I933, abrogating the gold clauses, which has provoked the most vehement legal repercussions in the international field. ${ }^{26}$ This statute applies to all gold clauses governed by American law, regardless of residence or nationality of the parties and of the place where the contract was made. Gold clauses have been customary in American contracts for many decades. They are almost invariably incorporated in government, municipal and private bonds offered to the public and in urban mortgages, also to a great extent in rural mortgages and in life insurance policies. The amount of obligations affected by the joint resolution has been evaluated to be more than one hundred and twenty billion gold dollars. That means, owing to the devaluation of the dollar, there has been a release of debts to an amount of more than forty billion dollars. Included are foreign bonds issued and placed in the United States figuring approximately to twelve billion gold dollars. Furthermore countless contracts in Europe and elsewhere have been based on gold dollars without any material connection with the United States, simply because the parties expected to have, by this clause, the best protection against unexpected monetary vicissitudes. Such cases do not come, in my opinion, under American law, unless there are special circumstances justifying the contrary decision. Therefore uncertainty and unrest provoked by the joint resolution are not limited even to the forty billion gold dollars mentioned above. Never in the field of private law has a statute had a financial and territorial effect comparable to that of the joint resolution. Unfortunately, the effect was a negative or rather destructive one. But the measure, preceded by numerous similar laws in other countries, ${ }^{27}$ was unavoidable. The American and the similar foreign statutes are not the cause, but the unambiguous expression and the official

${ }^{26}$ The international effects of the joint resolution are more closely examined in Nussbaum, Comparative and International Aspects of American Gold Clause Abrogation, 44 Yale L. J. 53 (I934). Further references may be found there.

${ }_{27}$ To the references given in 44 Yale L. J. 53 (1934), n. 35-5I, may be added Brazil: Law of November 27, r933, Bulletin de l'Institut Juridique International (r934), $26 x$. 
acknowledgment of the breakdown of investment and long-time credit. They represent an incisive and definitive curtailment of world economy.

It is well known that the constitutionality of the joint resolution has been challenged in several cases. The Supreme Court has not yet spoken, but up to the present the New York Court of Appeals and two courts of first resort have affirmed the constitutionality, ${ }^{28}$ and they are curiously joined by an Austrian court which was faced with the application of the joint resolution in a case concerning the American tranche of the international federal loan of Austria, I930. ${ }^{29}$ Only an Ohio State Judge of a court of first resort has held the contrary. ${ }^{30}$ We do not intend to deal here with the problem of constitutionality. For an international examination of the joint resolution, the first question to be answered is on what legal system, under private international law, the valitity of a gold clause depends. In this respect, an important precedent is available. The Serbian state issued bonds, before the world war, stated in "francs-or" and payable at the option of the holder in Paris and in several places outside France (Belgrade, Brussels, Geneva, Berlin, Vienna) being variously combined among the different issues of the bonds. After the war the Serbian government refused gold payment on the ground that the gold clause was abrogated by French law. An analogous position was taken by the Brazilian government with regard to certain Brazilian bonds. Hence a dispute arose between the French government protecting the rights of the French bondholders on the one hand and the Serbian and Brazilian governments on the other. The Hague Permanent Court of International Justice, to which the case was submitted, held for the French government, that is, for the bondholders..$^{3 x}$ The opinion applied French law, which, however, in international contracts upholds gold clauses. For our discussion, only the fact that the court decided on the ground of French law, is in point. The judgment asserts that, the bonds being issued by a state, are, in general, governed by domestic (Serbian, Brazilian) law, but that the validity or nonvalidity of the gold clause is linked with the question of payment and must, therefore, be judged according to French law, since owing to the text of the bonds "payment must or may be made in France." The reasoning of the court, in my opinion, is not well founded, as I have attempted to show elsewhere, but it has influenced national courts of different coun-

${ }^{28}$ Norman v. Baltimore \& Ohio Ry. Co., N.Y. L. J., July I9, I934; In re Missouri Pacific R. R. Co., 7 F. Supp. I (r934); Kennedy v. Conrad, 78 Congr. Rec. (April 4, r934), 6ro7.

${ }^{29}$ Bezirksgericht Wien, Innere Stadt (I934), Die Rechtsprechung 83 .

${ }^{30}$ In Equitable Life Insurance Society v. Freda, 78 Cong. Rec. (March I5, 1934), 4622. 3r Journal du droit international (r929), 977 . 
tries. Referring to the American situation, it follows from the doctrine of the Permanent Court that non-American bonds are likewise concerned by the joint resolution, provided they are phrased in gold dollars and absolutely or optionally payable within the United States. It may even suffice for the application of American law that either of these two requirements is met. The famous Panama case, ${ }^{32}$ for instance, involving a gold dollar compensation granted to Panama by the United States for the control of the canal zone, would probably come within the scope of the court's argument.

But even if, according to the general rules of international law, American law would apply, then in the continental legal systems, the conception of "public policy" (ordre public) would possibly interfere. According to this notion, an individual foreign ruling-although foreign law would be applicable in itself-may nevertheless be disregarded in case it violates the "public policy" of the state of jurisdiction. As regards the joint resolution, several non-American courts, however, have laid down the opinion that the public policy of their states does not forbid the application of the joint resolution. The courts could not help realizing that the joint resolution was not enacted in order to injure creditors, but in answer to an irresistible economic necessity. This view was advanced especially by a Hague court in the case of the Royal Dutch (Shell) and the Batavia Petroleum Company. ${ }^{33}$ An appreciation like this has to be given more weight, as Holland is one of the few countries that have not touched the gold clauses, and as Dutch public opinion is extremely irritated by the contrary attitude of the American and other legislatures.

The blow inflicted upon creditors by the abrogation of the gold clause is, indeed, a very grievous one. Bondholders have founded associations for protecting gold clauses. It is reported that steps have been taken by the associations with governments of states having invalidated the clauses. It seems even the associations have partly been backed by governments of creditor nations. There exists indeed a precedent for handling the questions through diplomatic channels. In I903 the United States, together with other powers, entered a protest against the president of Guatemala because of a decree abrogating, in a veiled form, the gold clauses; the loss imposed upon the holders of Guatemala gold bonds was evaluated at more than eighty per cent. Guatemala yielded to the protest, and the decree was repealed. I cannot discuss in this article the bearing of this precedent.

${ }^{2}$ N.Y. Times, March 3, I934, p. 7.

33 Weekblad van het Recht (March 8, I934), M I27I9. 
Still it seems to me that the economic world crisis has created a new situation also with regard to gold clauses.

The joint resolution, however, itself restricts, to a certain extent, the field of its application. Its subject matter is exclusively debts payable in American dollars. Obligations, for example, to pay Canadian dollars in gold, are not contemplated, even though they be taken over by American residents or citizens. Of course, corporeal delivery of gold coins is legally impossible within the United States under the president's ordinances of March and April, I933, but the debtor would in our example remain liable for the value of the Canadian gold dollars. Nor does the joint resolution abrogate promises guaranteeing to a non-American dollar creditor the original value of the dollars in terms of the creditor's domestic currency. In this instance a case recently decided by a French court may be mentioned. In June, I932, an American bank guaranteed to a Frenchman who expected to get successive dollar payments of altogether one million dollars within a two-year period the Paris rate of the dollar of June, I932, hence the full gold value of the debt, for a commission of 15,000 dollars. The bank was held liable to meet its obligation to the full extent. ${ }^{34}$

In the case of international loans, bondholders are very often given an option of place and currency of payment. Thus a bondholder may be entitled on the strength of a pre-war bond to receive in New York roo United States dollars, or in Paris 525 francs, or in Amsterdam 249 guilders. Another type of bond runs as follows: (debtor is bound to pay) \$roo in New York, or in Paris or Amsterdam the equivalent in local currency, at the current rate of exchange on New York. The first provsion gives an option between definite amounts, originally equivalent, in different currencies, contractually independent of each other (option de change). In the second case there is a basic or standard currency, exclusively determining the amount of the debt; only the place of payment is left to the choice of the holder (option de place). Similar clauses are to be found in non-bonded international obligations and in international insurance. For the option de change as well as for the option de place it is universally admitted that the option is in the creditor (holder), even if the bond be silent on this point, and irrespective of the country where the bond, if any, was issued. ${ }^{35}$ The effect of the dollar depreciation, however, would be com-

${ }^{34}$ Tribunal civil de la Seine (Oct. 26, r933), II Gazette du Palais (I933), 877.

${ }_{35}$ Several decisions to this effect are quoted in Nussbaum, Vertraglicher Schutz gegen Schwankungen des Goldwerts (1928), 70, n. 4. Among later and conforming decisions should be mentioned the judgment of the French Court of Cassation, July I7, 1929, Journal du droit international (1929), 1075 . 
pletely different in either case. In the first the creditor would not suffer any loss, for he might get the amount of guilders as stated in the bond or contract, in Amsterdam, but in the second case the amount to be paid in Dutch currency diminishes according to the depreciation of the dollar. Therefore, the distinction between the two kinds of options is extremely important and has been in issue in numerous law suits, particularly on the occasion of the franc depreciation. ${ }^{36}$ The situation becomes still more involved if the dollar amount is combined with a gold clause. It would be tiresome to examine every possible combination of places, currencies and gold clauses, but in short it may be said, that if we are faced with a mere option de place and the gold dollar is the basic currency, the joint resolution must apply, provided American law governs the case. This is true, in all events, for gold dollar bonds issued in the United States in the customary form of American bonds.

It is self-evident that the preceding discussion does not bring up all pertinent problems of the dollar depreciation. It is intended merely to draw attention to certain consequences of monetary developments which are, and may become even more, a troublesome element in international legal relationships.

${ }^{36}$ Cf. ibid., 7r, n. 2. 